\title{
VANADIUM POISONING FROM GAS TURBINES
}

\author{
BY \\ R. C. BROWNE \\ From the Nuffield Department of Industrial Health, University of Durham \\ (King's College, Newcastle upon Tyne)
}

(RECEIVED FOR PUBLICATION AUGUST 24, 1954)

Vanadium pentoxide poisoning has been described in men working in plants processing vanadium ore by Symanski (1939) and Sjöberg (1950), and twice (Wyers, 1946 ; Williams, 1952) in men exposed to the soot of fuel oil burned in boilers. It does not, however, appear to have been described before in men who work on gas turbines. Since these may become much more common in the future as sources of power using residual fuel oil for generating stations, ships, and locomotives, and also possibly for cars and omnibuses, it is worth bringing together the medical, engineering, and preventive aspects of the problem as far as they are known at present.

Vanadium is found in all fuel oil and remains in the residual heavy oil after the more volatile fractions, such as petrol, paraffin, and diesel oil, have been distilled. It is, therefore, only a consti- tuent of the exhausts of gas turbines using heavy residual fuels. Vanadium, which is present in the natural oil in complex compounds, appears as the pentoxide after combustion, and this forms an acid solution in water.

To improve the thermal efficiency of some types of gas turbine, the exhaust gas is made to heat the air from the compressor, and this is done in a heat exchanger which may take the form of a large metal box filled with tubes, outside which the hot exhaust gas flows. The intake air is inside the tubes which are arranged in a particular configuration. The products of combustion are deposited on the outside of these tubes. But in some types of heat exchanger the relative situations of exhaust gas and intake air are reversed, and in these the products of combustion will be deposited on the inside of the tubes. The 12

TABLE

ANALYSIS OF SYMPTOMS

\begin{tabular}{|c|c|c|c|c|c|c|c|c|c|c|c|c|c|c|c|c|c|}
\hline \multirow[b]{3}{*}{$\begin{array}{l}\text { Patient } \\
\text { No. }\end{array}$} & \multicolumn{6}{|c|}{ Respiratory System } & \multicolumn{5}{|c|}{ Alimentary System } & \multicolumn{3}{|c|}{ Skin } & \multirow{3}{*}{ Other } & \multirow{3}{*}{ Total } & \multirow{3}{*}{\begin{tabular}{|} 
Days \\
before \\
Symp- \\
toms
\end{tabular}} \\
\hline & \multicolumn{2}{|c|}{ Nose } & \multicolumn{4}{|c|}{ Chest } & \multicolumn{2}{|c|}{ Black } & \multirow[b]{2}{*}{$\begin{array}{l}\text { Odd } \\
\text { Taste }\end{array}$} & \multirow[b]{2}{*}{ Nausea } & \multirow[b]{2}{*}{$\begin{array}{l}\text { Diar- } \\
\text { rhoea }\end{array}$} & \multirow[b]{2}{*}{ Sore } & \multirow{2}{*}{$\begin{array}{c}\text { Smart- } \\
\text { ing } \\
\text { Eyes }\end{array}$} & \multirow[b]{2}{*}{ Rash } & & & \\
\hline & Blocked & $\begin{array}{c}\text { Bleed- } \\
\text { ing }\end{array}$ & Cough & $\begin{array}{c}\text { Breath- } \\
\text { less }\end{array}$ & $\begin{array}{c}\text { Wheez- } \\
\text { ing }\end{array}$ & $\begin{array}{c}\text { Tight- } \\
\text { ness and } \\
\text { Pain }\end{array}$ & Tongue & Teeth & & & & & & & & & \\
\hline 1 & + & & & & + & + & & & & & & & + & & & 4 & 1 \\
\hline 2 & & & + & & & & + & & & & & + & & & & 3 & 4 \\
\hline 3 & & & + & & & & & & & & & & & & + & 2 & $\begin{array}{c}\text { Not } \\
\text { known }\end{array}$ \\
\hline 4 & + & + & & & & + & + & & & + & + & & & + & & 7 & 14 \\
\hline 5 & & + & + & & & & + & + & + & & & & & & & 5 & 3 \\
\hline 6 & + & + & + & + & + & & & & & & & & & & & 5 & 2 \\
\hline 7 & & + & & & & & & & & & & & & & & 1 & 3 \\
\hline 8 & & & & & & & + & & + & & & & & & & 2 & 7 \\
\hline 9 & & & + & & & + & + & & & & & & & & & 3 & 2 \\
\hline 10 & & + & & & & + & + & + & + & & & + & & & & 6 & 7 \\
\hline 11 & & & + & + & + & & & & + & & & + & & & & 5 & 2 \\
\hline 12 & + & & & & + & + & & & & & & & + & & & 4 & 1 \\
\hline Total & 4 & 5 & 6 & 2 & 4 & 5 & 6 & 2 & 4 & 1 & 1 & 3 & 2 & 1 & 1 & Avera & ge : $4 \cdot 2$ \\
\hline
\end{tabular}


affected men in the present description were working inside a heat exchanger cutting away the tubes with pneumatic chisels. The exhaust air from these made a dust, and after an average time of just over four days in these conditions the men complained of the symptoms shown in the Table on page 57.

Two out of 12 of the men noticed symptoms in one day, three in two days, two in three days, one in four days, two in seven days, and one man was only affected after 14 days' exposure. Nose bleeding was the first symptom in five men and, in general, the acute respiratory symptoms of cough, tightness or pain in the chest, wheezing or breathlessness, predominated, followed by alimentary and skin effects. Eight of the men complained that their tongues or teeth had become black, and four of having an odd taste in the mouth. A few said they had a sore skin or smarting eyes, but only one man complained of a rash. After exposure to the vanadium pentoxide was stopped the symptoms of black tongue or teeth ceased in from two to four days, but the respiratory symptoms took from seven to 14 days to disappear. The symptoms in the present series of cases are generally similar to those described by Williams (1952), except that there was bleeding rather than running of the nose. Skin effects were not noticed in his series, nor mental depression in this series.

\section{Chemical Engineering}

The deposit on the outside of the heat exchanger tubes which the men were cutting away was heterogeneous, and consisted of three layers of different composition which related to the different fuels which had been used (Fig. 1). The outer of these three layers formed dust much the most easily, so that the dust to which the men were exposed probably contained at the least $11 \%$ of vanadium,

Fuel Used

Deposit Composition

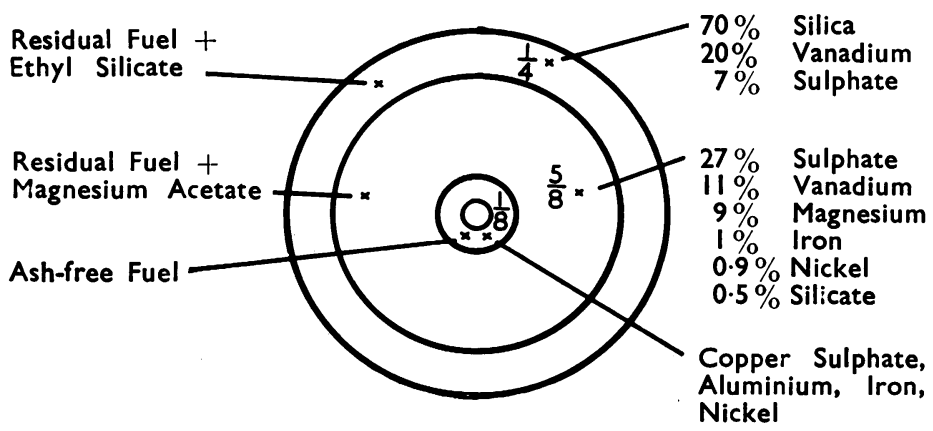

Fir. 1-Diagram of the three fuels used and the relative thickness and composition of the deposits which they formed round the heat exchanger tubes. and at the most $20 \%$. These figures are rather higher than those found $(6 \cdot 1$ to $12.7 \%)$ in the soot of the oil-fired boilers described by Williams. But the ash analysis of a normal residual fuel supplied by the Petroleum Board may contain as much as $62 \%$ of vanadium pentoxide (Hughes and Voysey, 1949).

\section{Prevention}

The prevention of this type of industrial vanadium poisoning is complicated by the fact that the dust produced forms an acid solution in water which irritates the skin. The working area in the present study was wet, and complete protection was afforded the men by dressing them in waterproof clothing, gum boots, and a civilian duty gas mask with an external air supply. There were no further symptoms after the prescription of this protective clothing, although the work continued as before.

Heat exchangers will probably be used in conjunction with gas turbines wherever efficiency is considered important, as in marine installations. But it may be that the tubes can be cleaned, other than manually, by blowing a jet of air or steam over them at a stage before they have developed much deposit. If they are found to scale up further after considerable use it may be possible to cleanse them chemically, and it is only if these two methods fail that men will need to work inside the exchanger. Further engineering experiments will be needed before it can be said which method or combination of methods works the best.

\section{Public Health Aspects}

All residual oils have a certain amount of vanadium in them, and the proportion appears to be higher in fuel from Venezuela. Gas turbines to use fuel of this type are at present being developed for ships, power stations, and locomotives, and it may well be that in the future diesel engines will also start using this fuel, because it is cheaper than the diesel oil at present used which is a distillate and contains no vanadium. In all these cases the exhaust, which may contain a vanadium respiratory irritant, will be discharged into the air.

Vanadium pentoxide, $\mathrm{V}_{2} \mathrm{O}_{5}$, is as great a nuisance to the engineer as it is to the doctor, since it corrodes the blades of gas turbines. Two methods are used to overcome this: either to introduce a metallic oxide or acetate with which the vanadium pentoxide 
unites to form an inactive vanadate, or to introduce a silicate so that vanadium silicate is formed which passes through the turbine as a fine dust. In the present experiments both these methods were used at different times, but the resulting deposits, presumably either vanadates or silicates, were still powerful irritants to the human respiratory tract, as shown by the symptoms of the men who inhaled them. The concentration of these compounds in the gas turbine exhaust is 20 to 60 p.p.m. (by weight), depending upon the temperature conditions under which the turbine runs. In the present experiments the inlet temperature to the turbine was $650^{\circ} \mathrm{C}$. It is not known what the concentration will be in the exhausts of diesel engines using residual fuel, but it may be higher due to the lesser quantity of excess air used.

In the future vanadium may take its place alongside sulphur dioxide and the carcinogens as part of the smog problem, but at present we do not know either what concentrations are likely in areas round power stations, or in their stack gases, or in a street of stationary diesel buses. Neither can we yet state the maximum permitted concentration in the atmosphere. Symanski (1939) showed that young men of good physique developed chronic bronchitis from working for a few years in a vanadium factory, and the work of Wyers (1946) strongly suggests that continued inhalation of these compounds causes chronic bronchitis and emphysema-and under his conditions quite rapidly. This suggestion is supported by the work of Sjöberg (1950), who demonstrated that rabbits which were exposed to 0.02 to $0.04 \mathrm{mg}$. per litre of vanadium pentoxide dust for one hour a day for eight months developed emphysema which could be seen post mortem.

\section{Summary}

Twelve cases of vanadium poisoning are described in men working in a gas turbine heat exchanger. The symptoms were acute irritation of the respiratory tract, with nose bleeding and blackening of the tongue and teeth. Irritation of the skin and eyes was also reported.

The vanadium was in the form of a silicate, vanadate or pentoxide, and formed 11 to $20 \%$ of the deposit on some tubes which the men were cutting away.

The immediate prevention of the condition is by means of waterproof protective clothing and breathing through a mask with an external air supply. Applied chemical engineering may make this job unnecessary in the future.

Gas turbines and diesel engines which use residual oil as a fuel will contain vanadium compounds in their exhausts to the atmosphere. This may provide a public health problem, but little is yet known about the concentrations concerned.

Acknowledgments are due to T. W. F. Brown, D.Sc., Director of the Parsons and Marine Engineering Turbine Research and Development Association, Wallsend, Northumberland, and his staff for help over the chemical engineering of this problem.

\section{REFERENCES}

Hughes, D. F., and Voysey, R. G. (1949). J. Inst. Fuel, 22, 197. Sjöberg, S. G. (1950). Acta med. scand., Suppl. 238. Symanski, H. (1939). Arch. Gewerbepath. Gewerbehyg., 9, 295. Williams, N. (1952). British Journal of Industrial Medicine, 9, 50. Wyers, H. (1946). Ibid., 3, 177. 